DOI: 10.17516/1997-1370-0663

УДК 159.9.07

\title{
Personal Determinants of Improving Sports Effectiveness Among Young People
}

\author{
Yulia V. Slobodchikovaa, Irina V. Semchuk ${ }^{\mathrm{b}}$, \\ Elena V. Skvortsovac and Oksana A. Musatova*d,e \\ ${ }^{a}$ Department of Humanitarian and Social Sciences MIREA \\ Russian Technological University \\ Moscow, Russian Federation \\ ${ }^{b}$ Russian Academy of Education \\ Moscow, Russian Federation \\ ${ }^{c}$ Belgorod University of Cooperation, Economics and Law \\ Belgorod, Russian Federation \\ ${ }^{d}$ Russian National Research Medical University \\ Moscow, Russian Federation \\ ${ }^{e}$ Russian New University \\ Moscow, Russian Federation
}

Received 25.06.2020, received in revised form 04.09.2020, accepted 10.09.2020

\begin{abstract}
The article focuses on the issue of improving athletes' performance. The subject of the research is personal determinants of improving the effectiveness of sports activities among young people. The purpose is to identify personal determinants that predefine the effectiveness of sports among young people. In the process of studying personal determinants that predefine the effectiveness of sports among young people we applied the methods of logical, theoretical and comparative analysis, content analysis, interpretation and scientific data interpretation, generalisation and modelling. On the basis of theoretical analysis the study identified the most significant personal determinants for the increase in the effectiveness of sports among youth, developed a theoretical structural and functional psychological "Personal determinants of improving the effectiveness of sports among young people" model and determined the interrelation of intrapersonal structures mediating the process of the influence of biological, social and individual personal determinants to increase the effectiveness of sports among young people.
\end{abstract}

Keywords: personal determinants, young people, improving the effectiveness of sports, model.

Research area: education.

\footnotetext{
(C) Siberian Federal University. All rights reserved

* Corresponding author E-mail address: uvs-1601@yandex.ru, semchirina10@yandex.ru, skvorcova.ev2012@yandex.ru, muoxa@mail.ru

ORCID: 0000-0002-1257-0284 (Slobodchikova); 0000-0001-9620-4494 (Semchuk); 0000-0003-1932-3443 (Skvortsova); 0000-0001-8893-4059 (Musatova)
} 
Citation: Slobodchikova, Yu.V., Semchuk, I.V., Skvortsova, E.V., Musatova, O.A. (2020). Personal determinants of improving sports effectiveness among young people. J. Sib. Fed. Univ. Humanit. Soc. Sci., 13(9), 1559-1572. DOI: 10.17516/1997-1370-0663.

Youth sports are the foundation of the nation's health; therefore, much attention is paid to the sports movement in any civilised country.

Regular sports activities significantly increase physical performance and positively affect the intellectual activity of a person. Therefore, experts say that the influence of sports on the human body is irreplaceable because systematic physical exercises develop general endurance, strengthen health, improve moral and volitional qualities and form a general positive emotional background. In the modern world, when the population of many European countries is getting older (there is an increase in people with high life expectancy), and the birth rate is becoming much lower, pension coverage looms on the problem-horizon, so one of the most important issues is the length of a person's working capacity.

However, social functions of sports activities, in relation to humanity as a whole or to an individual in particular, are different. Talking about a particular person, sport is a means of self-improvement, an opportunity to develop physical skills to the highest possible level. It is sport that allows a person to recover poise, form a critical attitude to mistakes and develop introspection and self-observation. Of course, the above is extremely relevant for today's young people.

High performance sports develop an individual's ability to observe, assess the situation quickly and react fast. Both physical and intellectual development is required for an athlete not only to study specialist literature, but also to critically analyse their own advantages and disadvantages, make decisions in time-limited situations and precisely perform tactical and strategic elements of the contest. Sport enables athletes to form such character traits as honesty, desire to help, kindness and selflessness in the course of performing tasks that are associated with training and competitions.
Sport is an extremely effective tool for the formation of a socially valuable individual. The need to perform significant amounts of training loads lays the foundation for hard work, discipline and teamwork, which means that it meets the needs of a person in an emotionally intense spare time. Significantly, sport fulfills a socio-political function strengthening international contacts, developing and promoting peace and international solidarity.

The key issue in sports is the athletes' performance growth, within the scope of which, based on the study of specialised works of both domestic and international scientists, the authors identify a number of different points of view.

By the way of illustration, Jack J. Lesyk highlighted as key such basic psychological indicators that affect athletic performance as motivation, positive attitude, the ability to set realistic goals, create positive mental images, the ability to overcome negative emotions and anxiety regardless of anyone, as well as the ability to effectively communicate with people around us (Lesyk, 1998).

V. Krane and J.M. Williams discovered that the most significant psychological characteristics of athletes are: the ability to set goals, increased concentration, self-regulation, motivation and high levels of self-confidence (Krane, Williams, 1998).

Dr. Steve Brennan (Ph.D.), in his research highlights such psychological qualities that are inherent in the individual: cohesion, confidence, motivation, communication skills, leadership, maturity, integrity and mental balance and confidence (Khairullin, Frolov, 2018).

Thus, domestic scientists A.M. Akhatov and I.V. Rabotin confirm the opinion of international researchers and temperament is considered the core personal property that determines the effectiveness of an athlete. After all, the temperament is based on innate properties of the nervous system and has a stable combination of dynamic features of the indi- 
vidual's psyche (activity, emotionality, etc.) (Akhatov, Rabotin, 2000). E.P. Il'in, taking into account the structure of psychological indicators of the athlete, also identifies such indicators as equanimity, mobility, strength, lability, the author also points to the properties of the personality's temperament: extroversion or introversion, anxiety, lability and rigidity, activity and sensitivity (Il'in, 2008). Similar views are followed by Professor of the Department of Psychology of the Russian State University of Physical Education, Sport, Youth and Tourism V.F. Sopov who highlights the main psychological indicators of an athlete, such as individual biological properties, which include temperament and properties of the nervous system (Sopov, 2010).

V.P. Ozerov, a Russian scientist, developed a theory of levels of psychomotor abilities of an athlete. These levels include psychophysiological abilities of athletes in varying degrees of manifestation and different combinations (Ozerov, 2002).

Similarly, other domestic experts in the field of sports psychology, for example, Iu.M. Bludov, V.A. Marishchuk, A.D. Plakhtienko and L.K. Serova attach high importance to psychomotor differences of athletes. Specifically, sensorimotor reactions of an athlete, coordination, speed of actions, reaction to a moving object, memory, balance, proprioreceptive functions, muscle and joint sensitivity, distribution and switching of attention (Marishchuk et al., 1984).

Russian scientists believe that the motivational sphere of the individual is extremely important. Thus, one of the key psychological features is motivation for sports activities. Also important are the motives that encourage a person to work professionally.

The motivational sphere of the modern sportsman is recognised by Soviet and, subsequently, Russian scientists as the most important, even fundamental in the effectiveness of this type of activity.

The level of ambitions of young athletes, the direction of motivation to avoid failures and achieve success was studied by E.P. Il'in. The scientist described the process of an athlete making a decision about choosing a partic- ular sport through motives and personal values (Il'in, 2008).

One of the most prominent sports psychologists R.M. Zagainov is at the same time an outstanding practitioner who has repeatedly stated in his works the importance of the personal component of a young athlete. He considers the focus and motivation to win in sports as a character-forming personal trait of the champion. After all, under the direct supervision of R.M. Zagainov many were brought up to be Olympic champions in various sports (Zagainov, 2006).

V.F. Sopov appears to offer the most advanced practical and theoretical models of psychological qualities, for example, a model of factors needed to achieve the highest sporting result. The scientist included six factors in this model: motivation, information space, biopsychic resonance, psychotechnical minimum of personality, behaviour management and compliance with the models of training sessions (Sopov, 2010).

Thus, the model of the personality of a successful athlete, a champion, must include individual personal and biological blocks.

Russian scientist L.L. Serova also compiled her own author's model of an athlete's personality, which, in addition to motivation, included communicative, emotional, volitional and even gender blocks (Serova, 2006).

The above models emphasise psychological qualities of an athlete. This is the identification of key properties from the position of the profession that ensure success of a highly qualified athlete. These models make it possible to identify the level of these qualities in line with the methods but do not answer the question about a systematic approach to the effectiveness in professional sports.

R.A. Akhmetov also worked on the problem of efficiency in sports, finding a solution through mathematical formulae. Thus, he deduced the dependence of the athlete's performance on his physical parameters (Akhmetov, 2011). The topic of mathematical processing of the forecast of sports performance was supported by D.A. Abramov and S.O. Mikhalkin. Their Forecast of Sportsmanship by Individual Characteristics of Psychometric Indica- 
tors was written on the example of wrestlers (Abramov, Mikhalkin, 2006).

In other words, various author's models of psychological qualities of athletes achieve a strong position in methodology. However, a model that fully reflects the parameters that affect the performance of young athletes has not yet been developed. It is also necessary to develop a theoretical model of athletes' performance that could reflect the specifics of both individual and team sports.

Our research is based on the following principles of psychology: a generally accepted in the national science principle of consistency, which was proved by B.G. Ananiev, A.N. Leontiev and B.F. Lomov; such founders of Russian psychology as L.S. Vygotskii, V.V. Davydov, A.V. Petrovksii and D.B. Elkonin validated the principle of development; scientists K.A. Abulkhanova-Slavskaia, B.G. Ananiev, A.A. Bodalev, V.P. Zinchenko, A.V. Petrovskii and V.A. Petrovskii developed the principle of activity in modern psychological studies and, naturally, the principle of determinism (S.L. Rubinstein, A.V. Petrovskii, M.G. Iaroshevskii).

Our research is based on the theories and concepts of personality (B.G. Ananiev, A.N. Leontiev, A.V. Petrovskii), and takes into account the activity approach in Russian psychology developed by L.S. Vygotskii, A.N. Leontiev and B.F. Lomov.

Thus, based on the theoretical analysis of the main author's approaches of scientists engaged in the development of this problem, we identify the most significant personal determinants of improving the effectiveness of sports among young people. We developed a theoretical structural and functional psychological "Personal determinants of improving the effectiveness of sports among young people" model and conducted a study.

The object of the research is representatives of youth engaged in sports.

The subject of the research is personal determinants of improving the effectiveness of sports among young people.

The purpose of the research is to identify the personal determinants that predefine the effectiveness of sports among young people on the basis of theoretical analysis and experimental verification of the proposed provisions.

\section{Research objectives:}

1. Generalisation of the state of study of the problem under consideration.

2. Development of the theoretical structural and functional psychological "Personal determinants of improving the effectiveness of sports among young people" model.

3. Determination of the characteristics of personal determinants of improving the effectiveness of sports among young people. Identification of a group of personal factors that determine the formation and development of improving the effectiveness of sports among young people.

4. Development of recommendations for improving the effectiveness of sports among young people.

Working hypothesis of the research:

- Biological, social and individual personal determinants significantly influence the effectiveness of sports among young people.

- Adequate high self-esteem and ambitions significantly influence the effectiveness of sports among young people.

- High motivation to achieve success significantly influences the effectiveness of sports among young people.

Empirical base of the research. The study was conducted between 2018 and 2020, fifty-eight people were observed (fifty athletes aged 10-16 and eight coaches). Expert coaches and senior coaches of the Publicly Funded Institution of Moscow Oblast "Olympic Reserve School for Water Sports" with the experience of five to fifteen years and more and higher professional institution graduates.

Methods of research. The following methods were applied: content analysis, theoretical analysis, comparative analysis, logical analysis, interpretation of scientific data, generalisation, modelling empirical methods: questionnaire, conversation, analysis and self-analysis, testing, survey, overt observation and expert evaluation method. The study used Dembo-Rubinstein methods of self-esteem measurement and the motivation test by A.A. Rean.

The effectiveness in the field of physical education and sports is determined by the ra- 
tio between the results and the expenditure on activities in an effort to improve the results and reduce costs at the same time. Personal qualities have a different impact on sports performance growth among young people.

In modern psychological studies, determinants of personality are considered as a group of factors that determine the formation and development of a personality. The most studied determinants are biological, social and individual personal ones.

The dispute regarding the relationship between the social and the biological in man dates as far back as a debate between Z. Freud and A. Adler. Z. Freud considered the sexual instinct, i.e. the biological mechanism, to be the basis of all human psychic life, and A. Adler saw the desire for excellence, i.e. the mechanism of social origin, to be the basic one.

In Russian psychology it is also a debatable issue. While K.K. Platonov considers personality as a biosocial structure, another idea is that biological upon entering the personality becomes social.

That is, biological factors as hereditary certainly affect the effectiveness of sports in accordance with the requirements of a specific type of an athletic activity.

Social factors (environment) also affect the personality of an athlete. This includes the specifics of upbringing, behavioural norms that are accepted in the inner circle, family, received in the company of friends or social groups. Social factors continue to affect the individual in adulthood. The individual is socialised in the workplace and social roles, in turn, influence the individual, having an effect on human perception and behaviour. In other words, social factors are the most important component for improving the effectiveness of sports activities among the younger generation.

An important contribution to human socialisation is made by the family, the culture of its social environment. Social family factors are characteristics of the socio-cultural environment that seriously affects a particular person, thus forming their social dynamics and values.

Family values and forms of personal behaviour vary in different family environments and it is the reason why special importance is attached to the study of social family characteristics of young athletes in this work.

The model developed by the authors has an individual personal block that includes a person's self-esteem and motivation.

Self-esteem is one of the key properties of a person since it is a regulator of activity, thereby ensuring the best adaptation of an individual to the constantly changing life conditions.

Given the above, we can conclude that most researchers of the outlined mental phenomenon (I.S. Kon, 1978; G.V. Lozovaia, 2002; A.A. Rean, 1999; I.I. Chesnokova, 1977; G. Corey, 1990) distinguish it as the most significant in self-consciousness and self-concept of a personality.

Sports psychology is actively working on the issue of the role of self-esteem in the adaptive capabilities of the individual athlete with much research having appeared on this topic recently. Thus, we have been studying young athletes' self-esteem, especially self-esteem of athletes by gender types, the nature of self-esteem due to a certain professional activity and its relationship with a number of personal characteristics of athletes, the characteristics of self-esteem of athletes who work out and do different sports (O.V. Dashkevich, 1981; S.V. Zhilin, 2003; L.Z. Levit, 1988; G.V. Lozovaia, 2002; A.V. Malchikov, 1979; V.V. Medvedev, 1993; V.G. Norakidze, 1981; V.I. Palii, 1987; V.A. Pegov, 1988; R.V. Plashko, 2001; A.L. Popov, 2000, etc.).

According to the research by a number of authors (W. James, 1990; E.S. Kuz'min, V.E. Semenova, 1987; A.I. Lipkina, L.A. Rybak, 1968; A.V. Petrovskii, 1982; V.F. Safin, 1975; A.R. Spirkin, 1972; V.V. Stolin, 1983; I.I. Chesnokova, 1977), self-esteem plays one of the key roles in the life of any person, whilst being its "model" (according to N.B. Stambulova). Given this, it is interesting from the point of view of science and useful from the point of view of practice to study the questions that researchers have not yet answered. For example, the question of the level of the impact of self-esteem on the growth of performance in youth sports. 
It is difficult to talk about self-esteem without relying on such characteristic features of personal manifestations as behavioural motives or the level of claims.

Motivation, along with self-esteem, is of particular importance in professional activities, especially sports. The training process requires overcoming yourself and strong will, while motivation inspires a young athlete to win despite pain, fatigue and resistance.

High motivation shows additional potential in an athlete. The so-called second wind kicks in, a person works at the limit of their physical capabilities.

An athlete with a low motivation to achieve success simply gives up athletic classes at the stage of increased psychophysiological loads.

The theory of motivation for success and fear of failure was developed and advocated by A.A. Rean. This is a vector of the individual's aspiration in any activity, especially such a competitive one as sports. The level of aspirations of young athletes and their ambitions can be determined using this theory.

Scientific and methodological literature widely considers the issues of sports motivation, believing it to be a key factor in both successfully mastering and improving the skills of an athlete.
Based on the theoretical analysis of the basic author's approaches of scientists engaged in the development of problems of sports efficiency, we have identified the most significant personal determinants of improving the effectiveness of sports among youth and developed a theoretical structural and functional psychological model (Fig. 1).

Theoretical and methodological analysis of the subject of the research revealed the urgent need to include individualisation of training based on a personal approach in the training system of young athletes. The importance of the effectiveness of young athletes calls for high-quality solutions to professional problems. Hence, there is a natural interest in the problem of personal determinants of improving athletic performance.

Changing individual and personal determinants leads to an optimal level of athletic performance and activity. If one of the components of social factors is transformed, performance changes and sports performance deteriorates.

Individual and personal factors are strongly influenced by social and biological determinants of performance in sports.

Expert coaches were asked to fill in an athletes' performance log where each athlete's

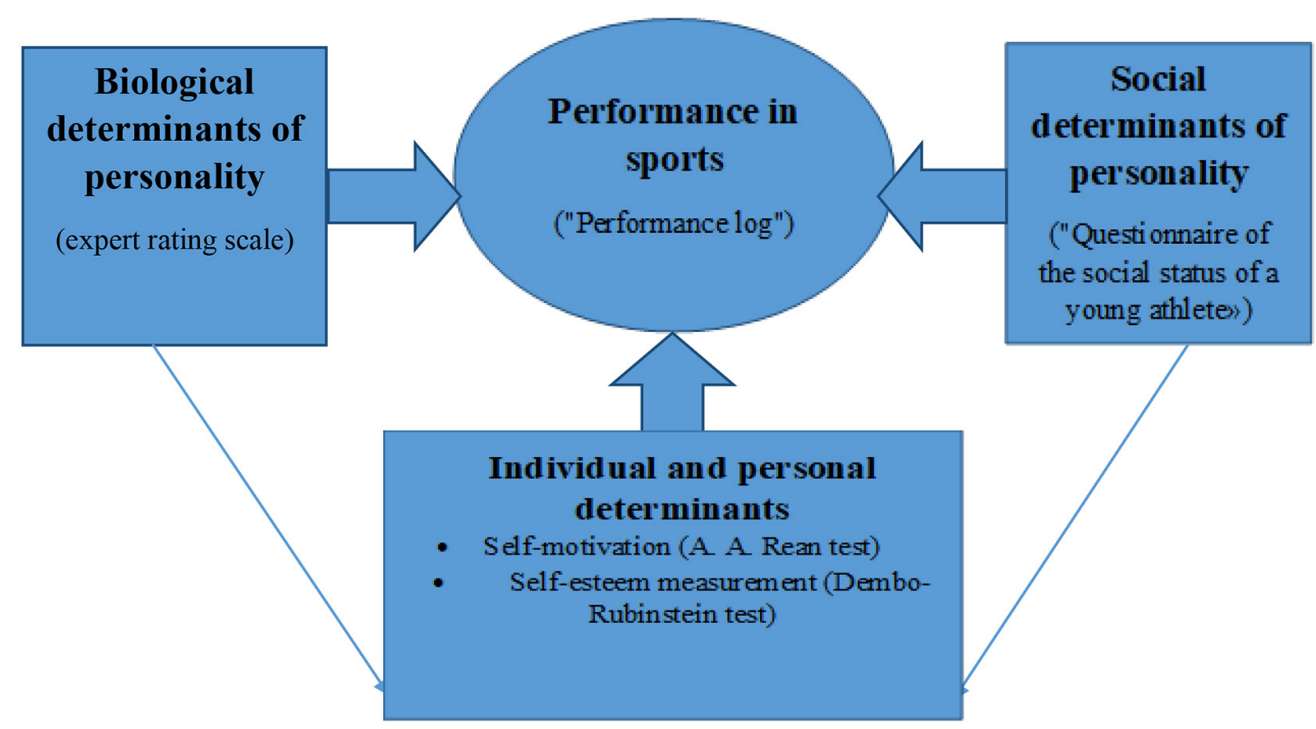

Fig. 1. Theoretical structural and functional psychological "Personal determinants of increasing the effectiveness of sports among young people" model 
scores are recorded on a ten-point scale and developed some criteria for the effectiveness of young athletes in this sport.

By effectiveness expert coaches mean the performance of an athlete.

The performance log also takes into account the speed of movement, the frequency and speed of reaction, which are significantly dependent on an athletic technique. Endurance is a very significant and necessary quality for a young person engaged in sports activities. At the same time, overall endurance was separately included in the effectiveness criteria, i.e. the ability to perform any activity for a long time, which involves the majority of muscle groups, as well as makes considerable demands on the body systems: respiratory, cardiovascular and central nervous. The same applies to special endurance which is due to the specifics of the requirements imposed on an athlete in the course of training in the chosen sport and is determined by the quality of condition of their organs and systems, physiological and mental capabilities relating to the chosen sport.

Special endurance is not only the ability to fight fatigue, but also the ability to perform tasks as effectively as possible under spacetime constraints.

Each athlete's effectiveness was assessed by their coach on a 10-point scale, where 10 is the maximum score and 0 is the lack of effectiveness.

Expert coaches also compiled a scale for evaluating the biological data of young athletes. In particular, the criteria reflecting the specifics of the given sport were included. These are, for example, height, weight, arm length, jump height, etc. This assessment was carried out by distributing young athletes in the following groups:

Groups of criteria:

"Excellent" (5) - biological factors of the individual fully correspond to the specifics of the given sport;

"Good" (4) - biological factors of the individual mostly correspond to the specifics of the given sport;

"Satisfactory" (3) - biological factors of the individual partially correspond to the specifics of the given sport;

"Unsatisfactory" (2) - biological factors of the individual do not correspond to the specifics of the given sport.

The study found that athletes were distributed according to this criterion as follows:

"Excellent" - 14 people;

"Good" - 25 people;

"Satisfactory" - 7 people;

"Unsatisfactory" - 4 people.

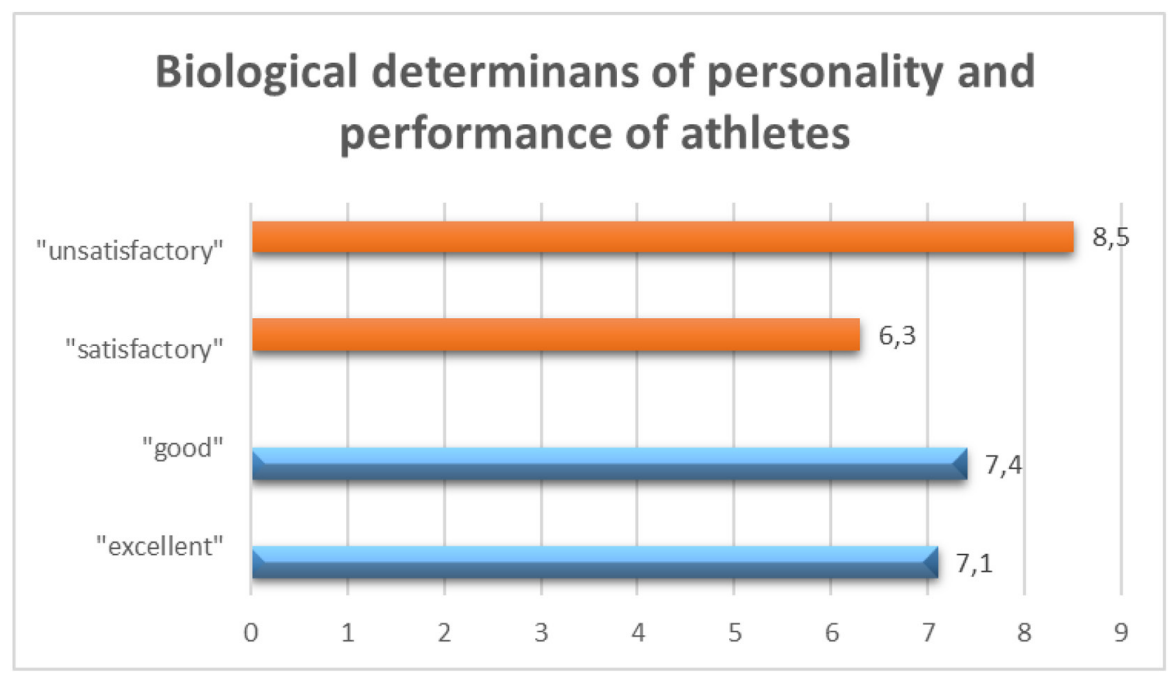

Fig. 2. Ratio of assessment issued by experts for biological indicators of athletes and in the athletes' performance log (points) 
This distribution of young athletes according to the biological criterion of the compliance with the given sport is not homogeneous. Most of the athletes received "good", the second place in the number of athletes is the group "excellent", there are also athletes who partially meet the requirements, of such $14 \%$. However, sports teams also train young athletes who do not meet the requirements of their sport according to their physical characteristics (in this case, it is the insufficient height of the athlete). The validity of the presence of such athletes in the team can be seen in the figure below.

In the course of the study, the following results were obtained: in a comparative analysis of the assessments, made by the experts evaluating the biological indicators of the athletes and in the athletes' performance log, the following trends can be registered:

- young athletes with excellent physical characteristics have the lowest performance indicators;

- young athletes with physical characteristics that do not meet the requirements of the given sport have the highest performance indicators.

To study social determinants of improving the effectiveness of sports among youth, we developed a Questionnaire of the social status of a young athlete. This questionnaire includes 23 questions that mainly clarify the composition of the family, living conditions, socio-psychological climate in the family, financial status and relationships between family members (Annex 1).

The following tendency appears among the most significant results: a considerable number of respondents (46\%) have bad family relationships. This can be explained both by adolescence issues and by the fact that it is important for young athletes with a negative socio-psychological climate in the family to realise their potential in a different group.

These results can be interpreted as follows: young athletes from families with socially unfavourable climate are more motivated for sports achievements. At the age of 10 to 16 athletes who are actively engaged in sports activities undergo natural (at their own request) and professional (coaching) selection in athletic classes and teams. Without high motivation and efficiency at this stage of the sports career, it is impossible to stay in the team as psychological and physical loads increase.

Based on the "Personal determinants of improving the effectiveness of sports among young people", a theoretical structural and functional psychological model developed by the authors, the study of individual and personal factors of young athletes was conducted in two directions:

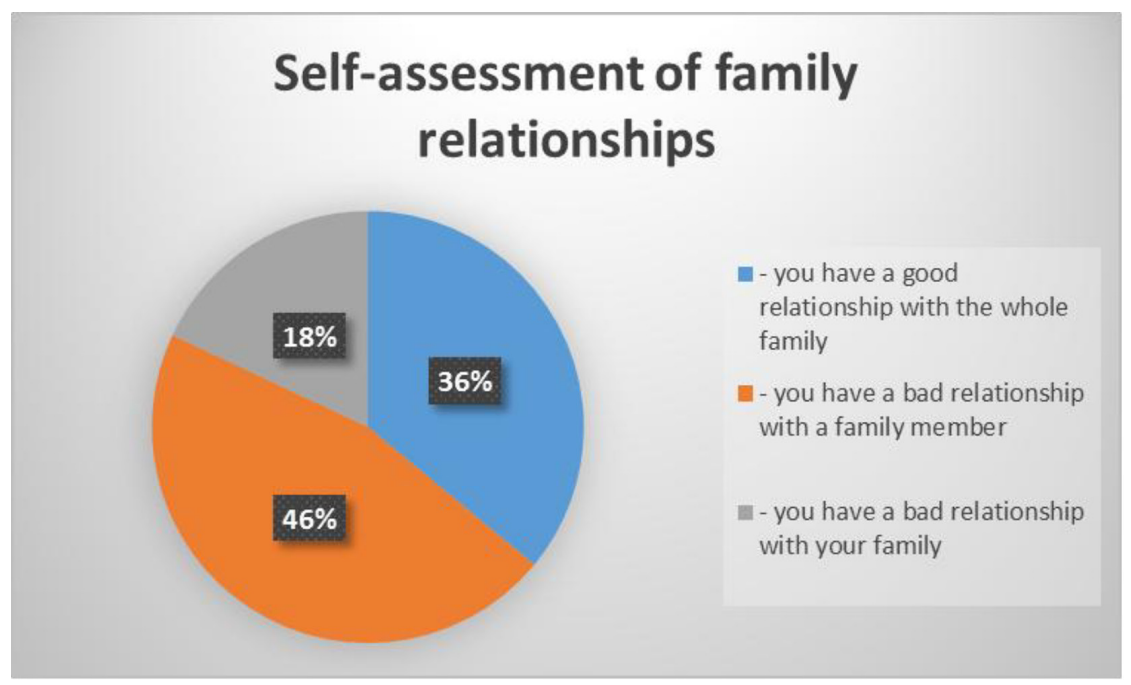

Fig. 3. Questions from the "Questionnaire of the social status of a young athlete" 
- motivation (Test. Motivation for success and fear of failure by A.A. Rean);

- self-assessment (Test. Self-assessment by Dembo-Rubinstein).

Delivering strong performances requires not only the ability to set complex tasks, but also understanding of how athletes are able to evaluate their own capabilities objectively and critically. Self-esteem is the opinion of an individual about themselves, their own capabilities and skills and has been formed as a result of comparing themselves with other people who are specialists in the fields of the activity under consideration, including sports.

We used the classic version of the Dembo-Rubinstein test in our research. The interpretation was based on the number of points:

- the level of adequate self-esteem is within the range of 50 to 75 points;

- the level of inflated self-esteem is within the range of 75 to 100 points;

- if the number of points is less than 50, it indicates low self-esteem.

The results of the level of aspirations assessment:

- from 60 to 90 points - realistic, adequate level of aspirations;

- from 90 to 100 points - unrealistic level of aspirations, excessive requirements for their own capabilities; tions.

- below 60 points - low level of aspira-

The following dynamics can be observed in Fig. 4. A fairly high level of self-esteem can be observed among the young athletes who said yes to "you have bad relationships in the family". This category also has the highest level of aspirations. This may indicate that low social status increases the level of aspirations, athletes with an unfavourable family environment try to compensate for their situation by having highly ambitious goals. Conversely, respondents who said yes to "you have a good relationship with the whole family" have a level of self-esteem closer to low and a lower level of aspirations. Young athletes who live in a more favourable family environment are comfortable with their position in society, there is no special desire for super achievements.

Study of motivation according to the test. A.A. Rean's test helps to determine the direction of the vector of personal motivation. After the research it becomes clear what drives a person: the desire for success or the avoidance of failure.

This determines the complexity of the task that a person sets for himself. The fear of failure, disappointment or the risk of victory are at stake.

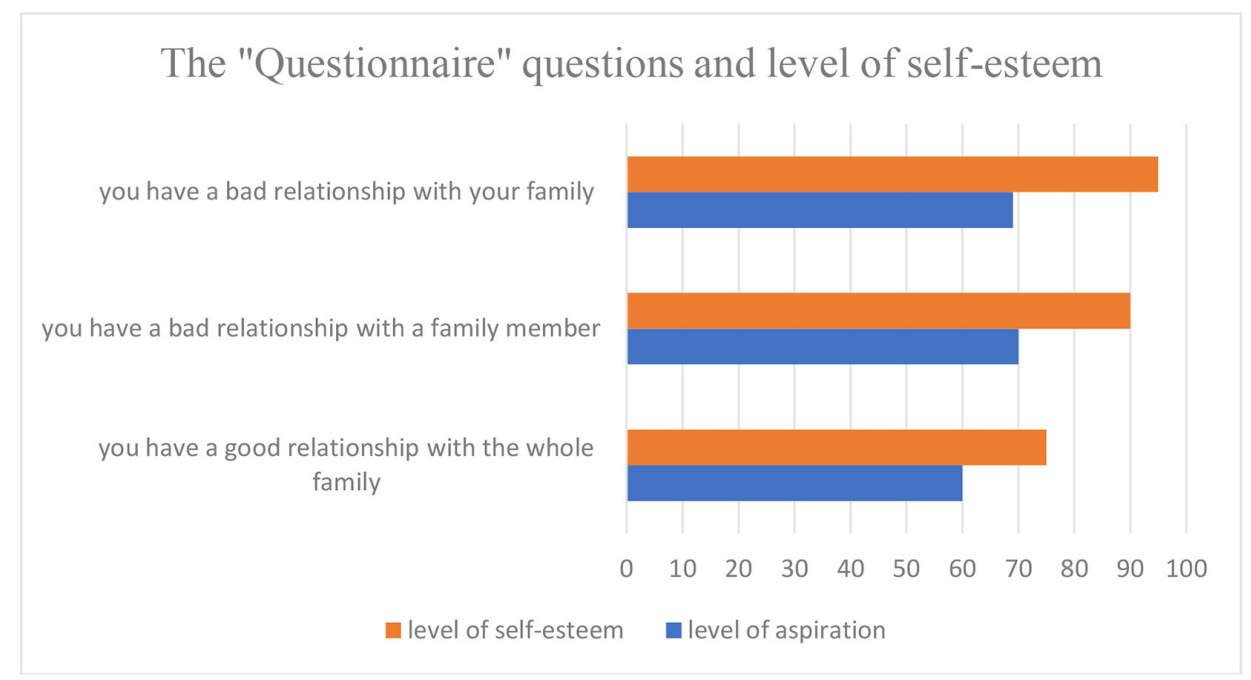

Fig. 4. Ratio of questions about the social status of a young athlete, the level of self-esteem and the level of aspirations according to the Dembo-Rubinstein test (points) 


\section{The ratio of answers to the "Questionnaire of the social status of a young athlete" to motivation for success (according to Rean)}

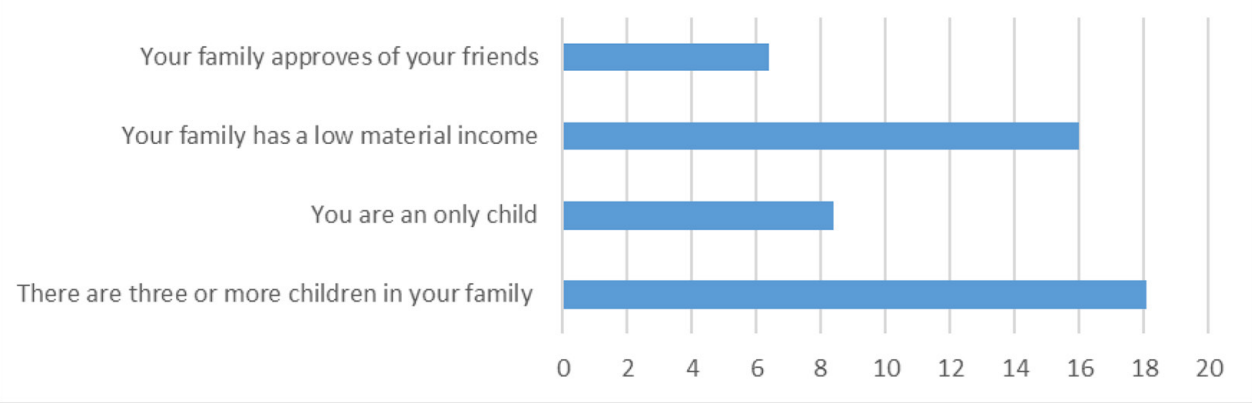

Fig. 5. Ratio of questions in the "Questionnaire of the social status of a young athlete" and the results of A.A. Rean's test of motivation for success (points) points:

The results are processed by counting

- motivation to achieve success if the subject scores from 14 to 20 points;

- undefined motivation if the subject scores from 8 to 13 points;

- motivation to avoid failure if the subject scores from 0 to 12 points.

Thus, in Fig. 5, the emerging trend is that the highest motivation for success is observed among the athletes who said yes to "your family has a low income" and "there are three or more children in your family". This can be explained by dissatisfaction with their position in the family and the desire to climb the social ladder. However, the motivation is closer to avoiding failure among the athletes who answered yes to "you are an only child" and "your family approves of your friends". The former can be explained by the fact that there is probably a child-centred environment in a family with only one child. The only child among adults is frequently surrounded by excessive care and attention, so they have a subconscious desire to stay in this comfort bubble by any means, and this is avoiding failure.

The latter, "your family approve of your friends", can be interpreted as the desire to be positively evaluated, if possible, to avoid con- flicts in the family, which also contributes to the motivation to avoid failure.

Fig. 6 shows the expected result. The higher the motivation for success, the higher the effectiveness of young athletes in sports is. Such results are described by both theorists and practitioners of sports psychology.

The results are summarised and analysed and are as follows.

Table 1 shows the most informative columns in the summary table of all research results and the following trends can be registered: those who responded positively to the questions of good socio-psychological climate in the family received the lowest ratings of their athletic performance $(6.1-6.4$ points on a ten-point scale); in addition, these respondents have a closer to low level of self-esteem and unexpressed motivation, prone to avoiding failure. Conversely, young athletes who indicated something negative in their family ("sometimes you are physically punished", "you have a bad relationship with your family", "your family has a low income") showed the highest performance indicators $(8.1-8.8$ on a ten-point scale). These athletes received the highest indicators of self-esteem and the level of aspirations (according to the Dembo-Rubinstein test) and motivation closer to achieving success (according to A.A. Rean's test). 


\section{Ratio of performance of young athletes to the motivation to achieve success (according to Rean)}

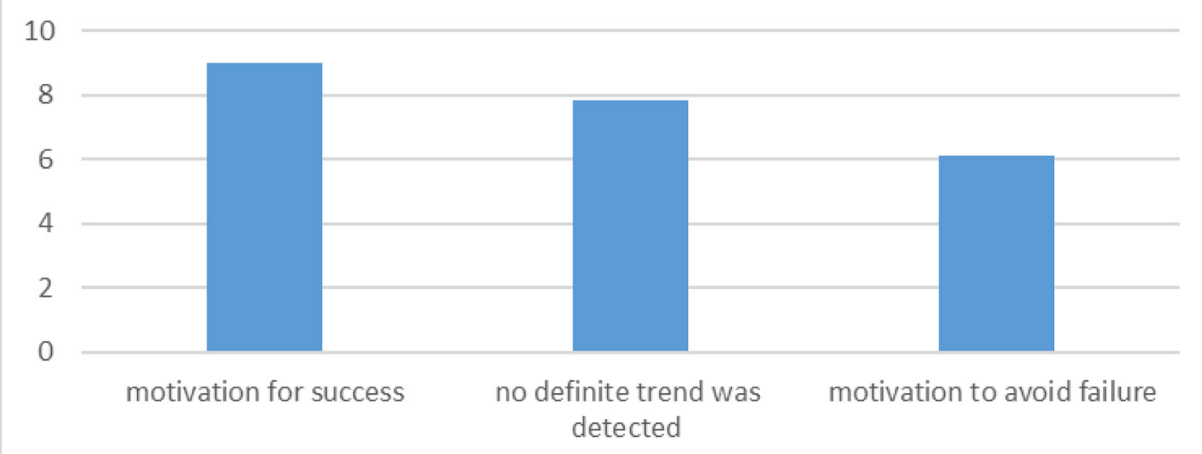

Fig. 6. Ratio of ratings from the athletes' performance log and the motivation of young athletes (according to A.A. Rean)

Table 1. Research results summary table

\begin{tabular}{|c|c|c|c|c|c|c|}
\hline № & Questions & 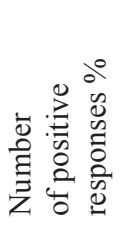 & 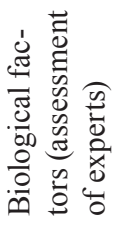 & 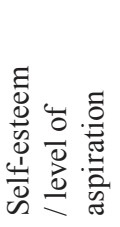 & 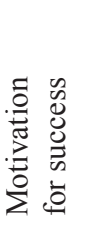 & 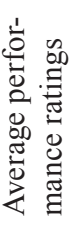 \\
\hline 1 & Do you live in a full family? (mother, father, child...) & $36 \%$ & 4.1 & $60 / 75$ & 9 & 6.1 \\
\hline 3 & You have a good relationship with the whole family & $42 \%$ & 4.5 & $55 / 70$ & 9.7 & 6.4 \\
\hline 4 & You have a bad relationship with your family & $18 \%$ & 3.9 & $79 / 95$ & 17.5 & 8.1 \\
\hline 5 & Sometimes you are physically punished & $26 \%$ & 3.8 & $60 / 90$ & 16.5 & 8.8 \\
\hline 6 & Your family has a low income & $24 \%$ & 4.1 & $60 / 95$ & 17 & 8.8 \\
\hline 6 & You are an only child & $14 \%$ & 4.8 & $70 / 75$ & 10.5 & 6.4 \\
\hline 7 & There are three or more children in your family & $40 \%$ & 4.5 & $70 / 95$ & 15.1 & 8.1 \\
\hline
\end{tabular}

\section{Conclusion}

Thus, the idea of this work is to study personal determinants of improving the effectiveness of sports among young people. The significance of the development of the topic is represented in the methodological development of the psychology of high achievements in sports.

Therefore, the results of the theoretical and empirical research can be formulated in the main conclusions:
1. Theoretical and methodological analysis of the problem under consideration shows the urgent need to introduce individualisation of training based on a personal approach into the training system of young athletes.

2. One of the main tasks determining the training of young athletes is to increase effectiveness, which is analysed here in the context of their professional activities, which involves a psychological study of 
their features, highlighting the specific requirements of specific sports to their personal qualities.

3. Performance indicators of such individual and personal determinants as self-esteem and motivation, which are important for improving the effectiveness of sports among young people, have many common features. Therefore, based on the theoretical provisions of the study, it is possible to identify several general criteria for development, including orientation, activity and motivation, adequate self-esteem.

4. Experimental study of the influence of biological, social, and individually personal determinants on improving the effectiveness of sports among young people reveals the relationship of intrapersonal structures that mediate this process.
5. Personal determinants of improving the effectiveness of sports among young people can be divided into biological, social, and individual personal ones. Biological determinants of personality are dictated by the specifics of a particular sport, social determinants are considered in the context of social and family relationships, individual personal determinants are regarded in the focus of self-esteem and motivation in sports activities. Moreover, high biological and social indicators do not always directly affect the effectiveness of sports among young people.

6. The influence of individual and personal factors, such as self-esteem and personal motivation on improving the effectiveness of sports among young people suggests further study, which is planned to be conducted at the next stage of the research.

\section{References}

Abramov, D.A., Mikhalkin, S.O. (2006). Sports mastery forecast based on individual characteristics of psychometric indicators [Prognoz sportivnogo masterstva po individual'nym kharakteristikam psikhometricheskikh pokazatelei]. In Materialy Vserossiiskoi konferentsii [All-Russian conf. proc.]. Moscow, 25-27.

Akhatov, A.M., Rabotin, I.V. (2000). Psikhologicheskaya podgotovka sportsmenov [Psychological training of athletes]. Moscow, Fizkul'tura i sport, 218 p.

Akhmetov, R.A. (2011). Otsenka effektivnosti trenirovochnykh protsessov na baze posledovatel'nogo resheniia zadach prognoza rezul'tativnosti sportsmenov [Evaluation of the effectiveness of training processes based on the consistent solution of the problems of forecasting the performance of athletes]. Zhitomir, Zhitomirskii gosudarstvennyi universitet, $258 \mathrm{p}$.

Human resource management. Available at: http://www.buffalostate.edu/offices/hr/pepds/sf/index. htm (accessed 20 September 2015).

Il'in, E.P. (2008). Psikhologiia sporta [Sports psychology]. St. Petersburg, Piter, 348 p.

Isaev, A.P., Abzalilov, R.Ia., Rybakov, V.V., Nenasheva, A.V., Korableva, Iu.B. (2016). Modelirovanie v sisteme adaptatsii i upravleniia sportivnoi podgotovkoi [Modelling in the system of adaptation and management of sports training]. In Chelovek. Sport. Meditsina [Human. Sport. Medicine], 2, 42-51.

Khairullin, I.T., Frolov, A.S. (2018). The problem of motivation of students to physical education classes [Problema motivatsii studentov k zanyatiiam fizicheskoi kul'tury]. In Materialy mezhdunarodnoi molodezhnoi nauchnoi konferentsii i "Tinchurinskie chteniia" [Proc. of international youth scientific conf. and Tinchurin readings]. KGEU, Kazan'.

Khairullin, I.T., Miftakhov, R.A. (2017). Metodologicheskie osnovaniia etnopedagogicheskikh traditsiy $\mathrm{v}$ fizicheskom razvitii molodezhi [Methodological foundations of ethnopedagogical traditions in the physical development of youth], In Nauchnoe obozrenie: gumanitarnye issledovaniia [Scientific review: humanities research], 5, 51-54.

Lesyk, J. (1998). The nine mental skills of successful athletes: A holistic model for assessing and teaching mental skills to athletes. Available at: https://www.sportpsych.org/nine-mental-skills-overview (accessed 15 October 2015).

Marishchuk, V.L., Bludov, Iu.M., Plakhtienko, A.D., Serova, L.K. (1984). Metodiki psikhodiagnostiki $v$ sporte [Methods of psychodiagnostics in sports]. Moscow, Prosveshchenie, $216 \mathrm{p}$. 
Ozerov, V.P. (2002). Psikhomotornye sposobnosti cheloveka [Psychomotor abilities of a person]. Dubna, Feniks+, 320 .

Saati, T. (1993). Prinyatie reshenii. Metod analiza ierarkhii [Decision making. Method for analysing hierarchies]. Moscow, Radio i sviaz', 320 p.

Serova, L.L. (2006). Lichnostnye kachestva sportsmena [Personal qualities of an athlete]. In Uchenye zapiski universiteta imeni P.F. Lesgafta [Scientific notes of Lesgaft University], 20, 23-27.

Sopov, V.F. (2010). Teoriia i metodika psikhologicheskoi podgotovki v sovremennom sporte [Theory and methodology of psychological training in modern sports]. Moscow, RGUFKSiT, $116 \mathrm{p}$.

The online self-improvement community. Available at: http://www.selfgrowth.com/experts/stephen brennan.html (accessed 2 September 2015).

Zagainov, R.M. (2006). Psikhologicheskoe masterstvo trenera i sportsmena [Psychological mastery of a coach and an athlete]. Moscow, Sovetskii sport, $106 \mathrm{p}$.

Williams, J.M., Krane, V. (1998). Psychological characteristics of peak performance. In J.M. Williams (Ed.). Applied sport psychology: Personal growth to peak performance. pp. 158-170.

\title{
Личностные детерминанты повышения эффективности занятий спортом представителей молодежи Московской области
}

\author{
Ю.В. Слободчикова , И.В. Семчук
}

Е.В. Скворцова ${ }^{\mathrm{B}}$, О.А. Мусатова ${ }^{\mathrm{r}, \mathrm{A}}$

${ }^{a}$ Институт инновационных технологий и государственного

управления МИРЭА

Российский технологический университет

Российская Федеращия, Москва

${ }^{\circ}$ Российская академия образования

Российская Федерачия, Москва

${ }^{8}$ Белгородский университет коопераџии, экономики и права

Российская Федерачия, Белгород

'Национальный исследовательский медицинский университет им.

Н.И. Пирогова (РНИМУ им. Н.И. Пирогова)

Российская Федерачия, Москва

${ }^{\circ}$ Российский новый университет

Российская Федерачия, Москва

Аннотация. В статье уделено внимание проблеме повышения эффективности
спортсменов. Предметом исследования служат личностные детерминанты повы-
шения эффективности занятий спортом представителей молодежи. Цель работы -
выявление личностных детерминант, предопределяющих повышение эффективно-
сти занятий спортом представителей молодежи.
В процессе исследования личностных детерминант, предопределяющих повыше-
ние эффективности занятий спортом представителей молодежи, были использо-
ваны логический, теоретический и сравнительный виды анализа, контент-анализ,
интерпретация научных данных, обобщение, моделирование.
В результате проведенного исследования на основе теоретического анализа вы-
делены наиболее значимые личностные детерминанты повышения эффектив- 
ности занятий спортом представителей молодежи, разработана теоретическая структурно-функциональная психологическая модель «Личностные детерминанты повышения эффективности занятий спортом представителей молодежи», выявлена взаимосвязь внутриличностных структур, опосредующих процесс влияния биологических, социальных, индивидуально-личностных детерминант личности на повышение эффективности занятий спортом представителей молодежи.

Ключевые слова: личностные детерминанты, представители молодежи, повышение эффективности занятий спортом, модель.

Научная специальность: 13.00.00 - педагогические науки. 